\title{
Correction: Exploration of surgical blood pressure management and expected motor recovery in individuals with traumatic spinal cord injury
}

\author{
Reza Ehsanian · Jenny Haefeli • Nhung Quach • Jacob Kosarchuk • Dolores Torres • Ellen D. Stuck • Jessica Endo • \\ James D. Crew • Benjamin Dirlikov (D) Jacqueline C. Bresnahan - Michael S. Beattie (iD) Adam R. Ferguson • \\ Stephen L. McKenna
}

Published online: 10 December 2019

(c) The Author(s) 2019. This article is published with open access

\section{Correction to: Spinal Cord \\ https://doi.org/10.1038/s41393-019-0370-5 \\ published online 24 October 2019}

In the original version of this article, one participant's sex was assigned incorrectly. In Table 1, the number of males in the 'Improvement' group was misstated as '13 (81.3)', instead of ' $12(75)$ ', and the number of females was misstated as '3 (18.8)', instead of ' 4 (25)'. As a result, the associated $p$-value has changed from ' 0.21 ' to ' 0.39 '. This has been corrected in both the PDF and HTML versions of the article.
Open Access This article is licensed under a Creative Commons Attribution 4.0 International License, which permits use, sharing, adaptation, distribution and reproduction in any medium or format, as long as you give appropriate credit to the original author(s) and the source, provide a link to the Creative Commons license, and indicate if changes were made. The images or other third party material in this article are included in the article's Creative Commons license, unless indicated otherwise in a credit line to the material. If material is not included in the article's Creative Commons license and your intended use is not permitted by statutory regulation or exceeds the permitted use, you will need to obtain permission directly from the copyright holder. To view a copy of this license, visit http://creativecommons. org/licenses/by/4.0/. 